\title{
Art Pedagogy - Contemporary Visual Art studies
}

Hans Örtegren

Docent Visual Arts Education

Department of Creative Studies in Teacher Education,

Faculty of the Arts,

Umeå university

hans.ortegren@umu.se

Anna Widén

Senior lecturer Visual Arts Education

Department of Creative Studies in Teacher Education,

Faculty of the Arts,

Umeå university

anna.widen@umu.se

\section{Abstract}

This article describes a collaboration between a university and an art museum. The Contemporary Art Museum in Umeå in northern Sweden is one of Sweden's largest art galleries for contemporary art. The collaboration involves a course called Art Pedagogy, where an art-pedagogical project is planned, conducted and presented. Two projects collected in the spring of 2018 were selected for analysis. The result show that a win-win situation may occur when actors with different competences and resources participate in a project. For this to happen the schools and teachers need to have an interest and be prepared for a project, with an initial understanding.

Keywords: Art pedagogy, contemporary art, university students, art project 


\section{Introduction}

Bildmuseet [The Visual Art Museum] in Umeå, Northern Sweden is one of the country's largest and most prominent contemporary art galleries. As part of Umeå University, the museum's mission as a public enterprise (rather than one primarily engaged in educational/research activities) sets it apart from other actors at the university. From an academic perspective, the museum's focus is on "the Third Mission" - interaction with the surrounding society. In keeping with national and international trends with regard to the contemporary art field's pedagogical leanings, the museum has focused on educational activities. The art gallery has its own workshop, which is open to the public, schools and groups. As part of the university, the museum's mission is also to collaborate with other departments and operations within Umeå University. Collaboration takes place both outside and inside the Faculty of Arts, of which the museum is a part. Since 1997, the Department of Creative Studies has been engaged in teacher training with an emphasis on the aesthetic subjects of crafts, art and music. Since 2009, the Department of Creative Studies has not only been part of the Faculty of the Arts, but has also been covered by the umbrella organization of the university's Umea School of Education. The collaboration between the Department of Creative Studies and Bildmuseet was established many years ago and has been facilitated in various ways by their shared faculty affiliation. For example, the leadership of various activities has natural meeting spaces and the faculty has contributed resources for department-wide collaboration which, in turn, has promoted the development of various joint projects.

The collaboration also benefits from personal interactions between museum curators and Creative Studies researchers.

\section{Art Pedagogy in Contemporary Art Forms}

The course in Art Pedagogy is a collaboration between Bildmuseet and the Department of Creative Studies. It has been offered to students previously, but its form and content were renewed in the autumn of 2017. The course has been created for a target group with a certain degree of understanding of the field, which means that students are expected to have some prior knowledge of contemporary art and certain skills in the field of art pedagogy. The objective of the course is for students to gain increased knowledge of contemporary art forms and concepts and to develop their skills in work involving art pedagogy. This is a remote course, with four in-person meetings (spread over two semesters). In between these meetings, studies are conducted independently via a digital learning platform. At the course meetings, Bildmuseet's exhibitions and presentation spaces are used as an important resource.

The first module of the course deals with different artpedagogical approaches and methods. The focus is on interactions with art in public spaces and in art institutions. In the second module, an independent project with an art-pedagogical orientation is planned and implemented. There is an examination in connection with the presentation and analysis of the project through images and text. One aim of the course is to give students an opportunity to explore concepts such as art-pedagogical methods and contemporary art from a theoretical and practical perspective. The course comprises lectures, exhibitions, group discussions and the testing out of different art-pedagogical methods and artistic design forms. The course progresses from learning about didactics, art pedagogy and contemporary art to the testing out of knowledge, skills and abilities through the planning and implementation of an independent aesthetic project.

\section{Project work}

In the course, an art-pedagogical project, is planned, conducted and presented. The project work is examined in the second part of the Art Pedagogy in Contemporary Art Forms course. The project is implemented in a real-life situation. In their project, students are encouraged to challenge past experiences, take on new target groups and try out new methods. The idea is for students to challenge their own understanding and gain new perspectives on their previously established knowledge. Thus, their project work will have a novelty value for the students. In some way or another, the project work will address the interaction between a work of art/exhibition and a target group of the student's own choosing. It will be carried out based on inspiration from an art-pedagogical method that fosters the 
understanding of contemporary art ideas and artistic processes. The fact that the project is authentically conducted also means that it has several objectives and dimensions. From a student's perspective, the project primarily focuses on the student's own learning goals - the project work must challenge the student's own competence and should therefore also entail some form of novelty value. However, secondary didactic purposes are also built into the project, because students also formulate work objectives from a participatory perspective.

\section{Two case studies}

Fifteen students were accepted to the Art Pedagogy in Contemporary Art Forms course conducted in the academic year 2017-2018. These included art educators, artists and students from the teacher education program. During the spring of 2018, approximately one dozen projects were completed within the context of the course. From this material, two projects were singled out as subjects for analysis in case studies. Both projects took place in public spaces in collaboration with an art gallery.

The data on which these case studies were based - text, photos and conversations recorded using digital equipment - were collected in the spring of 2018. The strategic selection represents two types of work:

- Project work which had a didactic purpose, with an emphasis on learning through active participation.

- Project work in which inclusion was sought, i.e. greater participation among young people belonging to the group called "inexperienced museum visitors".

\section{Case Study 1. Inclusion focusing on contemporary art}

In the first project, the challenge was to "... find new ways of fostering interactions with contemporary art". Here, the student addresses the challenge faced by art educationists in "... helping to awaken interest in contemporary art and creating a context that enables the participants' own exploration of both artistic processes and their own creativity." The art-pedagogical work was based on an exhibition of two-dimensional, abstract paintings that were displayed in an art gallery. The audience comprised mainly young people with little prior knowledge, and for whom Swedish was a second language. This project consisted of a work process in multiple parts: art mediation, practical and investigative work in various environments. The first part concerns an introduction to abstract art (featuring one artist's work) via a visit to an art gallery. In the next step, work was conducted at various sports facilities. This involved exercises as well as concept and material acquisition. Finally, the participants worked together with the artist in a temporary atelier. Each participant's work resulted in a poster, and these were presented in a parade during a major Swedish sports event (Photos

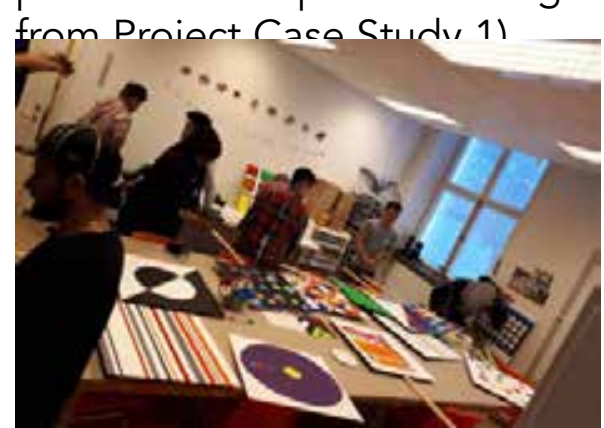

Photos from Project Case Study 1. Workshop

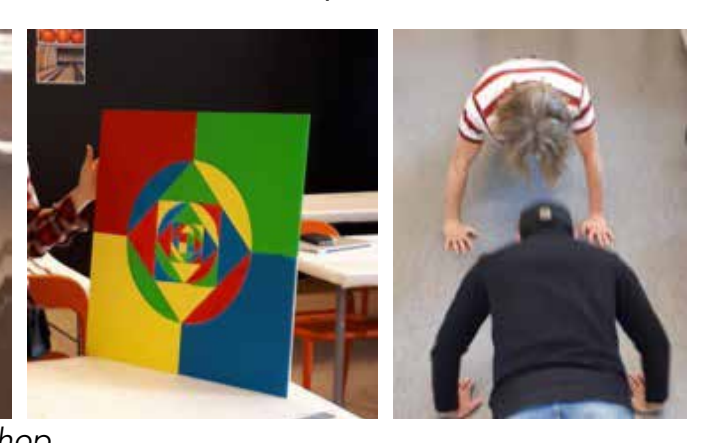

1. Posters are mounted 2. Almost finished poster 3. Exercises connected to sports

\section{Case Study 2. Inclusion focusing on art production}

In the project case study, the challenge lay in investigating the possibility of creating a breeding ground for successful integration into Swedish society through art and art pedagogy. The aim was to study how learning through active participation with the help of the arts and culture can contribute to an understanding of each other's cultures, differences and similarities. "It's important to be able to reach the participant, to get this person to actively participate in the exercise and to establish a creative learning process in order to achieve the intended goal and purpose". The art-pedagogical work was based on a sculptural work - an assemblage of various everyday objects all made of a common type of material - glossy, silvery and hard, which was exhibited in an art gallery. The project was carried out with a group of young people who had recently immigrated to Sweden. The students chose to implement their pedagogical practices through two different workshops. Each workshop was divided into 
two parts, and the work was based on the theme of things (which ties in with the work with which the participants had become familiar). As a first step, a short, guided tour was conducted and the young people had the opportunity to participate in image-analytical conversations about the same work of art - a sculpture. The next step - the investigation was based on methods of experimentation, exploration and, finally, the creation of work with various mediations. In one example, the resulting artwork incorporated paintings/drawings and in the second example, a sculpture/assemblage. Thus, the participants had the opportunity to try out the artist's perspective and methods. In both cases, the workshops ended with the presentation of the participants' own artistic representations and discussions about these works (Photo Project, ct, Case Study 2).
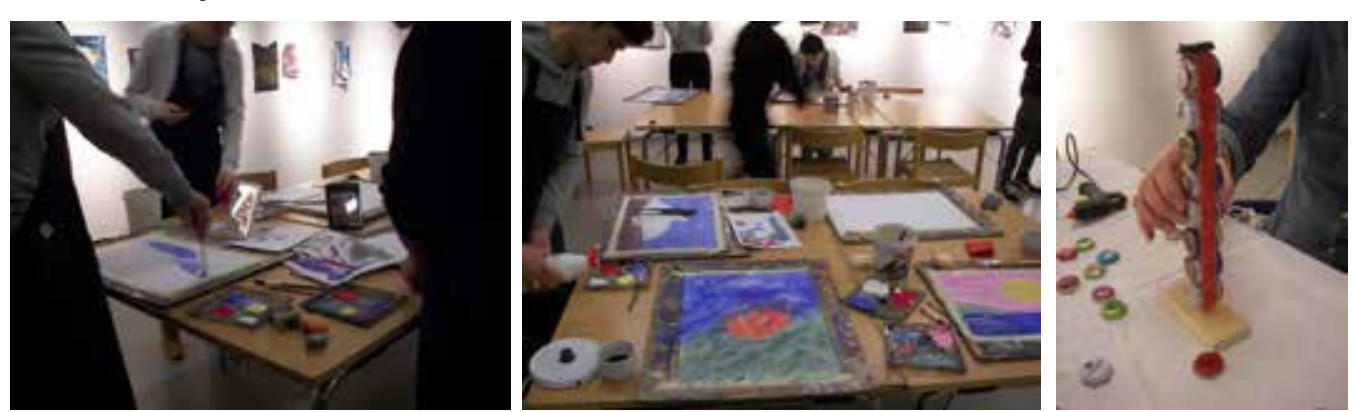

Photo Project, Case Study 2. Workshop

1. Create and shape 2. Sculpture, capsules/straws 3. Choice: familiar materials - painting

\begin{tabular}{|c|c|c|}
\hline Case Study & Case Study 1 & Case Study 2 \\
\hline Category & Access Inclusion - contemporary art & Access Culture - producing art \\
\hline $\begin{array}{l}\text { Student } \\
\text { learning - } \\
\text { perspective of } \\
\text { the task }\end{array}$ & $\begin{array}{l}\text { Challenge in finding new forms for creating } \\
\text { encounters with contemporary art }\end{array}$ & $\begin{array}{l}\text { Challenge in active participation and } \\
\text { learning through own production }\end{array}$ \\
\hline $\begin{array}{l}\text { Project - } \\
\text { formulated } \\
\text { purpose }\end{array}$ & $\begin{array}{l}\text { Increasing participants' interest in } \\
\text { contemporary art by creating a context in } \\
\text { which the participants explore artistic } \\
\text { processes and their own creativity. }\end{array}$ & $\begin{array}{l}\text { Methods that contribute to learning } \\
\text { and raising awareness of participants' } \\
\text { own culture. }\end{array}$ \\
\hline Methods & Inspire - investigate - find - make - display & Investigate - collect - make - reflect \\
\hline Target group & $\begin{array}{l}\text { Young people, aged } 16-21 \text { years with minimal } \\
\text { prior knowledge, upper secondary school. } \\
\text { Other native language. Differentiated } \\
\text { ethnicity. }\end{array}$ & $\begin{array}{l}\text { Young people, aged } 16-18 \text { years with } \\
\text { minimal prior knowledge. Other } \\
\text { native language. Diff. ethnicity. }\end{array}$ \\
\hline $\begin{array}{l}\text { Exhibitions } \\
\text { and used } \\
\text { Media }\end{array}$ & Contemporary art, 2-dim. painting & Contemporary art, 2-dim. assemblage \\
\hline $\begin{array}{l}\text { Exhibitions } \\
\text { And Themes }\end{array}$ & $\begin{array}{l}\text { Interactive works, participation "... The } \\
\text { audience is often invited to both change the } \\
\text { abstract patterns that his art often comprises } \\
\text { or physically engage in the artwork". }\end{array}$ & $\begin{array}{l}\text { Assembly of everyday objects - } \\
\text { Sustainability, Social critical } \\
\text { perspective }\end{array}$ \\
\hline $\begin{array}{l}\text { Proj. pres. } \\
\text { where-how }\end{array}$ & As a manifestation parade, outside in public & $\begin{array}{l}\text { At the art gallery, workspace, as an } \\
\text { assemblage and images, inside }\end{array}$ \\
\hline
\end{tabular}

\section{Comments}

Previous research (J. Widén, 2016) emphasizes the value of the primary art experience. This is also particularly significant in view of the way contemporary art demands participation and interaction. Both exhibitions and museum visits give the participant an opportunity to participate and even enter into the art physically. This is not possible if it is displayed as a secondary representation - for example, an image or a moving image viewed via a digital channel. The artpedagogical performative methods that contemporary art demands also lose their "charge" - their efficacy - when they are not viewed in situ. The Art Pedagogy in Contemporary Art Forms course seeks to find power in the spatial and location-specific experience.

These aspects position the art museum as a keystarting point for the design of the course.

The Art Pedagogy in Contemporary Art Forms course is based on both the museum's knowledge tradition and the research and 
development work of the faculty of the Department of Creative Studies in the teacher education program. When reflecting on the forms and roles of art pedagogy, we should remind ourselves that contemporary art also forms part of the larger context of "visual culture". Today, the visual is revealed in a multimedia context, with channels for the dissemination of a multitude of visual expressions with different messages and objectives. The children and adolescents of today's society relate to this power of choice in their daily lives. By highlighting contemporary art as part of visual culture, it becomes something familiar and non-foreign to many young people. Its mediations and message will be familiar. Participation through individual investigation, creation and conversation about art as visual culture can increase confidence in one's ability to communicate. Trying out and daring to use visual expressions can increase a person's ability to communicate, and thus a person's interest in art - as demonstrated in the first project (Case Study 1): "My hope is that the project can create an interest in Contemporary Art among young people and a willingness to continue to participate in similar processes in the future" (student, Case Study 1).

The two project case studies presented here emphasize the importance of being given space to explore contemporary art with the assistance of professional educators and teachers. Here, young people get the opportunity to analyse what they experience and see in a formal art discussion. They also have the opportunity to increase their understanding through meeting the artists behind the works and sharing stories about their own creative processes. In Case Study 1, the participants work together with the artist.

A partnership can provide an understanding of underlying ideas and themes. This can spark inspiration and increase the participant's own understanding of the creative process. Through deeper contact with the artist, young people can approach both the culture and the creation of art, and this can increase their confidence in their own artistic abilities and opportunities. Case Study 2 explored how cultural understanding and community can be increased through art. Art is brought closer and tells the participants something about culture. In the second project, contemporary art is highlighted as a means of illuminating democracy and citizenship. "Art is for everyone and my purpose of the project is to see how, in my role as an art teacher, I can help raise interest in contemporary art and create a context in which the participants' own exploration of both artistic processes and their own creativity is made possible" (student, Case Study 1).

\section{The role and significance of art pedagogy}

The two examples from the course highlight the value of defining target groups that primarily require support in order to experience and understand that art is something for everyone; it is a right. In Case Study 2, it appears that free creation in itself does not always lead to safe creative situations. Rather, a framework is needed - one based on an active didactic reflection with an awareness of different target groups. The student who conducted Case Study 2 reflects: "I thought that by giving a lot of free choice (within a certain framework), participants would feel/ .../ more free to create based on themselves and their reference frameworks and experiences. However, the effect was rather the opposite" (student, Case Study 2).

To increase visual knowledge and the capacity to express artistic forms, a physical visit to an art gallery can be enhanced through art pedagogy. Thus, a second valuable aspect is the role of art pedagogy as a resource in the use of art as a medium for learning and increased visual skills. The two cases of project work that are the subject of analysis in the studies were both implemented within the context of a course, but they were also conducted within the context of an art gallery. In both cases, examples are provided of how institutions outside of school can be used as a resource to enable the realization of authentic projects. The project work forms part of a university degree with a specializing in Art Pedagogy and is primarily focused on the student's learning. The project tests different art-pedagogical methods and the formal didactic purpose elucidates the participants' learning processes. Informal purposes/ objectives and effects are also incorporated. Informally, the project also has a reverse purpose that can strengthen democratic processes. This creates the opportunity for informal learning for all participating actors, teachers, artists and art gallery staff. 


\section{Visual Culture in school settings}

Since 2011, "Visual Culture" has been an area of study in the art curriculum (Sw. Bild) in Sweden. Taking an active part in our visual culture requires producing images and understanding and analysing works of art, including one's own art. Such skill requirements are in focus in at least three contexts in our society. First, visual culture is connected with the idea (and fact) that images are being dispersed through media and social media at an ever-increasing pace. The ability to adapt to the world outside the traditional school setting is constantly being discussed. The permeability between the school as an institution and other parts of society is of interest when it comes to major changes within society at large, including the increasing use of all kinds of images. Second, school curricula in general proclaim citizenship and democracy values to be a key competence along with personal development and skills connected to the capacity to master studies and prepare for the job market. Thus, each school subject attempts to provide a generic competence that can be easily linked to visual capacity or visual literacy. Third, in specific subjects such as art it goes without saying that visual knowledge is the core of the subject. At the same time "art" and "visual art", as rather limited forms of visual expression, have been challenged by the broader concept of "visual culture".

To highlight these competencies, we can compare secondary art education with other subject areas. Most students expect their study of art to be connected with making images with different objectives, i.e. as a compulsory subject, art is not considered by students to go beyond the production of images and their gradual accretion of art knowledge that permits them to produce images for different reasons. Similarly, students expect mathematics to focus on solving mathematical problems by gradually increasing their mathematical knowledge so this knowledge can be used for different practical and theoretical reasons. However, unlike the skills focus of art and mathematics, the social sciences (i.e. religion, history and civics) are subjects that present slightly different expectations. These subjects are necessarily based on facts alone, and focus on morality, ethics and beliefs that differ between times and cultures; and these subjects, along with learning facts, often focus on arguments for different positions. Although this focus on different arguments is found in mathematics, science and art, these arguments are less evident to most younger students. With regards to aesthetic subjects, arguments for analysis include a relative approach: we all have different tastes and nothing is either right or wrong. However, in the end, students use criteria that connect art with the skills of the individual art student.

From different perspectives, this notion of the "aims and means" of an aesthetic subject is not sufficient to be in line with written documents as curricula. There are different avenues to follow that balance the aims of curricula with the reality of the classrooms. Either you have to re-write curricula, or to change the teaching methods and to some extent the content knowledge of the subjects. Another way is to define the aims by working with the assessment criteria - that is, to change the curricula so it addresses the aims of the subject in question.

\section{European Network for Visual Literacy (ENViL) in a Swedish context}

In the ENViL study (Schönau \& Wagner (Eds.), 2016), a number of European curricula have been studied in relation to studying visual culture and visual literacy in all the arts. Funded through a UNESCO grant, this very ambitious project analyses one of the key competencies from 2006 called "Cultural awareness and expression". To connect to the domain of different literacies, the study covers visual literacy as part of the "old" key competencies, but with a broader focus. In reality, visual literacy contains a lot of the general generic competencies, but from a visual perspective.

Both Bernhard Darras (France) and Kevin Tavin (USA and Finland) have commented on ENViL. Darras finds that ENViL's critique model appeared to be connected with structuralism and concepts of image-making linked to modernism (Schönau \& Wagner, 2016 p. 380). Similarly, Tavin believes ENViL is based on structuralism as it views visual competence as a "language."

Our aim is to relate the ENViL to a Swedish context and to discuss the gains and losses in implementing the proposals stated. The way visual literacy and its competencies are described, we 
believe the core of the subject must be related to the art as a subject of study (Bild) and, in upper secondary school, to courses that are predominantly focused on Media and Art Programs linked to the visual field. Nevertheless, important elements of the competencies ought to be studied separately in other subjects or in combination with the arts. This also applies to the two case projects we followed in this article. The students were engaged in projects not specifically linked to a certain school subject, although their productions can be primarily linked to the art subject.

\section{The two case projects linked to Studio Thinking}

One way for both teachers and students to gain a better understanding of the capacity for visual literacy is to link it to the project and book Studio Thinking: The Real Benefits of Visual Arts Education (Hetland et al. 2007). This book identifies several general criteria called Studio Habits of Mind: Develop Craft; Engage and Persist; Envision, Express, Observe, Reflect, Stretch and Explore, Understand Art World. Through documentation, observation and interviews with identified "good examples" within art education in the United States, the identified habits were connected to three phases of art education: Instruction (often introductions by teachers); Students at Work (mainly focused on processes during production of images and objects); and Critique (reflections concerning the processes and achievement of aims during different projects). In the two case projects we discussed it is clear that the students have applied parts of these criteria to their work with their student groups.

\section{Instruction, Students at Work, and Critique}

In a way, at first glance you might simply connect the identified studio habits as ordinary ways of preparing, processing and evaluating a specific subject. By connecting these procedures to something that was also transferable to generic competencies, as well as by embedding the potential effects, the authors have come to call it "Studio Habits of Mind". However, the authors caution that you must not take it for granted that the effects of transfer can be traced between the learning outcomes in an art subject to other subjects. There is little evidence of such clear effects. Still, in this research project it could be claimed that the so-called "Studio
Habits of Mind" show potential generic competencies that are useful strategies for learning and creative thinking in subject areas other than art.

To a great extent, different methods for giving instruction are connected to the specific subject area. However, the examples show that the preparation of generic competencies and the focus on aims are more complex than just mastering subject-specific content. The section concerning students working focuses on how communication between teachers and students primarily takes place in order to discuss the skills associated with "making" (e.g. creating a piece of art) and to help students define their specific ideas and solutions. The "Critique" section mainly focuses on verbally exploring and explaining the process that led to completing tasks, i.e. the student's accomplishments.

\section{Discussing "making" visual imagery and visual literacy}

In the curricula up to lower secondary and upper secondary school level, art subjects rely on terms such as "visual culture," "visual art" and "images" - terms that relate to the ENViL terminology on visual literacy. One point in this article is that in school practice the subject of art is primarily about learning the competencies necessary to produce visual imagery. To keep aesthetic subjects like art connected to a subject of making paves the way for a deeper understanding of what a culture of "makers" is about.

It is not just about doing, but doing with different purposes, for different audiences, connected to different traditions. It is also production in contexts in which it serves as a means of understanding and interpreting other visual productions. The point is, it might be smart to integrate interpretations through visual productions. One advantage of this is that it connects with the student's general expectations (and their teacher's expectations) of the art subject as predominantly being a narrative on making. Another advantage is that digital media and tools sometimes make it easier to derive comparisons, understanding visual literacy by connecting it with their own experiences of making.

There has been a tendency for aesthetic subjects to copy 
the arguments of our most established school subjects such as mother tongue languages, mathematics and science (Marner \& Örtegren, 2015 c). These arguments vary but are generally focused on the basic knowledge needed as a citizen to read, write and calculate sufficiently well to get a job and possibly continue their education. The two case studies show that, in a Swedish context, new groups can receive the necessary help to be connected to visual arenas and had the opportunity of co-working with people outside ordinary school environments.

\section{Excellence and Access}

Moderna Museet [The Modern Museum] in Stockholm has a description of its ambitions that states "Excellence and Access" as being key concepts. In which case, it is obvious that "excellence" primarily refers to the artworks that are exhibited and "access" to the openness to the public (Örtegren, 2009).

Three different functions that can relate to how culture can be applied by people are Enlightenment and Bildung (humanistic model), Confirmation and Communication (sociological model) and Diversion and Experience (instrumental model) (Baklien, Pedrelli \& Franzén, 2002, according to Skot-Hansen). These models describe factual pedagogical strategies in which cultural activities can be studied in different target groups:

\begin{tabular}{|c|c|c|c|}
\hline Goals & $\begin{array}{l}\text { Humanistic } \\
\text { Bildung/ Learning }\end{array}$ & $\begin{array}{l}\text { Sociological } \\
\text { Emancipation }\end{array}$ & $\begin{array}{l}\text { Instrumental } \\
\text { Manifestation }\end{array}$ \\
\hline Background & The State & The civil society & The Market \\
\hline Audience & The people at large & Groups, i e pupils & $\begin{array}{l}\text { Segments - } \\
\text { life styles }\end{array}$ \\
\hline $\begin{array}{l}\text { Frame } \\
\text { Function }\end{array}$ & $\begin{array}{l}\text { Cultural institutions } \\
\text { Enlightment } \\
\text { Knowledge }\end{array}$ & $\begin{array}{l}\text { Active participation } \\
\text { Confirmation } \\
\text { Development }\end{array}$ & $\begin{array}{l}\text { Festivals } \\
\text { Enyoyment } \\
\text { Appreciation }\end{array}$ \\
\hline
\end{tabular}
to Skot- Hansen)
- Humanistic and Art- oriented links to the functions in cultural policies that are related to enlightenment/training/education. This strategy builds on placing the artefacts and musical pieces at the centre and emphasizing their importance from an artistic and educational perspective.

- Sociological - A more emancipatory approach (confirmationcommunication) can be compared to Relations-oriented. This strategy aspires to a more enduring and long-term own activity for the visitor/ participant. This is the strategy we have in focus regarding co-creative aspects.

- Instrumental - The third strategy initially focuses on visibility and experience and is called Experience-oriented. It can be described as an attempt to connect with the participant and offer a personal experience of participation in a cultural event.

Borgen (2014) describes three other models for checking relationships and collaborations between schools/teachers and professional artists/cultural workers in schools from the Norwegian programme The Cultural Schoolbag. It comprises a partnership model, an integrated and an external model. These categories have been extracted from the roles the participants play and whether or not the evaluations offer the basis for negotiating between the partners. The first model is characterized by a clearly defined partnership and the projects are time limited and well defined.

The second model refers to art and culture as integrating the school's content and subjects. The meetings between the partners are integrated in the schools' aims and system. The visiting professionals have clearly prescribed roles.

In the external model, schools are offered the opportunity to buy programmes by artists, as well as art and cultural organizations. The schools can be seen as recipients of programmes in which external forces take care of the evaluations. This leads to less scope for negotiations between the parties, i.e. between teachers/ students on the one hand and cultural workers on the other. The projects 
might also be called "external" when the teachers not are notified about the projects, or do not participate together with their classes and the external artist/cultural worker. Possible exchanges and shared learning between teachers and other agents tend not to appear, as well as the opportunity to follow up what has been taught. The external model may also be considered to be typical of a distributive view of culture, and can be seen as compensation for a lack of culture within the schools in this case.

If we combine these different models we can see some common denominators. If the term co-creation is to really be filled with content you would expect that the students involved and their teachers would be able to further develop the cultural activities in their own school environment to promote long-term experiences.

Schools are generally not considered to be the cultural institutions that they actually are, but rather that they require outside support to be able to take part. In Sweden, recent evaluations have been made that have highlighted a requirement for more long-term initiatives in cultural events in which schools play an active role and are not primarily seen as consumers of professionals that visit schools or take charge of projects without any lasting engagement from teachers and students. (The Swedish Agency for Cultural Analysis 2014).

\section{Discussion}

A win-win situation may occur when actors with different competences and resources participate in a project. Different actors can use each other's skills and resources to create a win-win situation. In order to create a win-win situation in a cooperative project involving several institutions, it could be important for schools and teachers to already have an interest and therefore be prepared for a project, with an initial understanding and a degree of knowledge.

If there is no special interest to start with there is a risk that a project will become a top-down project, implemented on teachers overburdened with work who are therefore seeking some form of relief by connecting external experts to school.

The two examples we have given from the Art-pedagogical course show that we think that the normal and everyday situation in design education, and in many other areas in school, could preferably comprise projects and emphasized external relationships. The schools of today no longer have a monopoly on knowledge, since other media, other institutions and other cultures are natural partners in building the students' competence, knowledge, skills and understanding. In fact, it is easy to see both museums and schools that belong to different fields of culture opening up and realizing that they are instruments and institutions for communication.

This means that complete communication processes, including production and presentation, may be an important method in design education, and in artistic education and in learning generally. In such cases the student really takes part in the learning process and is not an object of the teacher's teaching. However, complete communication processes demand an infrastructure in school and out of school including studios, workshops, media studios, venues for performance and exhibitions, etc (Marner \& Örtegren 2015, a, b).

This focus is also connected to an interpersonal aspect of relationships between students and other actors, such as friends and relatives. This may be called an existential argument for design in school. In a relation between a past, a present and a future, the student relationship to a surrounding space, in total, a life world. This individual perspective on design education, and on arts and crafts education, relating artistic activities in school to the student's identity, that artistic activities are interesting and fun etc., is important, yet it is not enough. It may be too narrow an argument since it highlights creativity that is related to spare time and leisure only.

In many ways the ideas behind co-creation in the application and realization of the Umeå 2014 Cultural Capital was to involve citizens at all levels. Although, in many respects, the year was successful, there was a lack of genuine bottom-up activities, partly because the organization was too focused on already "excellentmarked" cultural institutions. A way needs to be developed for identifying easier avenues for schools to play an active role in performing their own projects, in which the "access-marking" becomes an important factor for taking part in events. One possible approach could be to consider how to combine so that the access 
argument is combined with excellence, but excellence that is not primarily related to professionalism but to dedication and strong co-creation. Good examples of such approaches are the examples we have analysed from the selected projects 1 and 2 .

\section{Concluding remarks}

The focus has been on students (at different levels) producing visual artefacts for different communication aims. One aim is to develop communicative skills in order to produce visual narratives for societal and democratic purposes as an informed citizen. A second aim is to produce visual narratives of poetic and/or personal views in specific areas of visual culture. A third aim is to produce tutorials or explanations with visualized and other media to provide information about the use of analogue and digital tools in order to explore these possibilities.

If these three aims are connected to making narratives, the subjects of Art or Visual Culture may benefit something. Through different ways of production, students can develop their knowledge connected to consumption and understanding of visual culture more broadly. Through production, the ability to process, reflect and analyse their own and others' visual productions can generate a somewhat deeper understanding. By embedding more digital devices and tools, it is also plausible that the connection between production, distribution, consumption and reflection of visual culture can be more easily integrated into the art subject.

\section{The model of emancipation}

For teacher training, the collaboration not only paves the way for the incorporation of competency, but is also an opportunity to provide training in which projects can be tested in real-life situations. In the development of teacher training courses in art-pedagogical activities and schools, as well as for other leaders of children's and youth activities in cultural contexts and arts school activities, it is important to stress the significance of testing things out in real-life projects. It is also important that in their communication, young people have access to the field's reallife expressions and concepts. This is where media-specific and medianeutral perspectives enter the picture. It should also be emphasized that collaborations should occur on equal terms between different actors.
If the didactic purpose of a collaborative project involves learning through active participation, then the ownership of the project by schools (rather than actors outside the educational environment) could help ensure that it achieves its goal. In a broader perspective, this ties in with larger goals in the emancipation model.

The aim of course content such as a real-life project is to conduct education that is as close to reality as possible in various social activities. Researchers and lecturers at the Department of Creative Studies cooperate with other educational activities in which practical pedagogical elements take place in workspaces outside normal educational activities. Some examples of this can be found at the training school in Vasa (Åbo Akademi University) and the Teacher Training Programme at University College, Copenhagen (UCC). Since its inauguration, Bildmuseet has frequently been used as a learning resource in teacher education specializing in the visual arts. Its learning resources include exhibitions, projects and personnel. Resources in the Visual Arts Teacher Training Program include elements of artistic practice. This activity now forms a permanent part of the syllabus. Students in the Visual Arts Teacher Program receive school classes and engage in other types of groups with participants of different ages. They plan and conduct discussions and exercises of an artpedagogical nature. This participation gives them the opportunity to engage in practical reflection. These elements give the students the opportunity to participate in real-life activities with professionallyactive museum educators in learning environments. Through their training, these students gain insight into the museum's activities and familiarization occurs via active participation. New forms of inclusion in an institutional art context increase the likelihood that tomorrow's teachers will interact frequently and comfortably with art institutions in their future teaching practice. This can increase the opportunities of educators to work with new pedagogical methods, as well as their ability to face the challenge of entering into different cultural contexts as active participants. 


\section{References}

Arvedssen, K. \& Mathiesen, F. (2018). Billedkunstdidaktik [Visual Art Pedagogy]. Hans Reitzel.

Aure, V., Illeris, H. \& Örtegren, H. (2009). Konsten som läranderesurs syn på lärande, pedagogiska strategier och social inklusion på nordiska konstmuseer [Art as a learning resource - views on learning, pedagogical strategies and social inclusion in Nordic art museums], NMA, publication 47.

Borgen, J. S. (2014). Asymetri mellom det "kunstneriske" og det "pedagogiske" i Den kulturelle skolesekken [Asymmetry between the "artistic" and the "pedagogical" in Den kulturelle skolesekken]. In: A. Elin \& S. Karlsnes (Eds.). Kunstner eller lærer? Professionsdilemmaer i musikk- og kunstpedagogisk utdanning (pp. 138-154). Oslo: Cappelen Damm Akademisk.

Eklund, S. (2002). Från teckning till pedagogiskt arbete i bild [From drawing to pedagogical work]. Umeåutbildningen till lärare i bild 25 år: Umeå: Umeå University.

Hetland, L., Winner, E., Veenema, S. \& Sheridan, K. (2007). Studio Thinking. The real benefits of Visual Arts education. Teacher's College Press.

Jonsson Widén, A. (2016): Bildundervisning i möte med samtidskonst [Visual Arts Education meeting Contemporary Art]. Diss. The Department of Creative Studies, Umeå University.

Kulturanalys 2014. The Swedish Agency for Cultural Analysis. Internet: http://www.kulturanalys.se/wp-content/ uploads/2015/02/Kulturanalys-2014.pdf.

Marner, A. \& Örtegren, H. (2008). Evaluation of the International Fantasy Design Project. Tilde ( ) Report no. 10/2008 Umeå: The Department of Creative Studies, Umeå University.

Marner, A. \& Örtegren, H. (2013a). Digitala medier i bildämnet - möten och spänningar [Digital media in visual arts - meetings and tensions]. In Marner, Anders \& Örtegren, Hans (Eds.) (2013). KLÄM - Lärande, ämnesdidaktik och mediebruk. Tilde ( ) document series no. 1. Umeå: Umeå University.

Marner, Anders \& Örtegren, Hans (2013a). Digitala medier i bildämnet - möten och spänningar. In Marner, Anders \& Örtegren, Hans (eds.) (2013). KLÄM - Lärande, ämnesdidaktik och mediebruk. Tilde ( ) document series no. 1. Umeå: Umeå University.

Marner, A. \& Örtegren, H. (2014). Digitala medier i ett bildperspektiv [Digital media as an visual arts perspective]. Erixon, PerOlof (ed.) (2014). Skolämnen i digital förändring - en medieekologisk undersökning [School subjects in digital change - a media-ecological investigation] (pp. 151-201). Lund: Studentlitteratur.

Marner, A. \& Örtegren, H. (2015 a). Synen på frihet i bildundervisning - fritt skapande eller intertextuell undervisning [The view on freedom in visual arts education - free creation or intertextual education] (pp. 87-123). In Tilde ( ), report no. 15, the Department of Creative Studies, Umeå University.

Marner, A. \& Örtegren H. (2015 b). Skön konst och/eller tillämpad konst - i bild och form och estetik och media [Fine art and / or applied art - in image and form and aesthetics and media] (pp. 124-175). In Tilde ( ), report no. 15, the Department of Creative Studies, Umeå University.

Marner, A. \& Örtegren, H. (2015 c). Bild i grundskolan. En nationell ämnesutvärdering i årskurs 6 och 9 (NÄU 13). [Visual arts in elementary school. A national subject evaluation in grades 6 and 9]. Stockholm: The Swedish National Agency for Education.

The Swedish National Agency for Education 2011. Läroplan för grundskolan, förskoleklassen och fritidshemmet/ grundskolan Lgr 11, Bild, [Curriculum for compulsory school, the pre-school class and leisure-time centre Lgr 11 Art].

Schönau, D. \& Wagner, E. (eds.)(2016). Common European Framework of Reference for Visual Literacy - Prototype Münster, New York: Waxmann.

The Swedish National Agency for Education (2013). Läroplan för gymnasieskolan Lgy 11, [Curriculum for the upper secondary school].

Wilson, C., Grizzle, A., Tuazon, R., Akyempong, K. \& Cheung, C.K. (2011). Media and information literacy curriculum for teachers (Unesco publication). 
Örtegren, H. (2012). The Scope of Digital Image Media in Education. Computers \& Education, 59, 793-805.

Örtegren, H. (2013). När digitala medier adderas till bildämnet [When digital media are added to visual arts]. In A. Marner \&

H. Örtegren (Eds.) (2013). KLÄM - Lärande, ämnesdidaktik och mediebruk. Tilde ( ) document series no. 1. Umeå: Umeå University.

Örtegren, H. (2014). Digital media added on to the subject of Art in secondary schools. Education Inquiry, 5(2), June 2014, 195214. 